\title{
Impact of Environmental and Pathogenic Variability on Breaking of Host Rust Resistance in Wheat Cultivars under Changing Climatic Conditions
}

\author{
Muhammad Makky Javaid ${ }^{1}$, Muhammad Zulkiffal ${ }^{1}$, Yasir Ali, ${ }^{2, *}$, Arshad Mehmood ${ }^{1}$, Javed Ahmed ${ }^{1}$, \\ Muhammad Hussain $^{3}$, Faqir Muhammad ${ }^{1}$, Waseem Sabir ${ }^{1}$, Muhammad Hammad Tanveer ${ }^{1}$, \\ Owais Yasin ${ }^{2}$ \\ ${ }^{1}$ Wheat Research Institute, Ayub Agriculture Research Institute, AARI, Faisalabad, Pakistan \\ ${ }^{2}$ Department of Plant Pathology, University of Agriculture Faisalabad, Pakistan \\ ${ }^{3}$ Plant Pathology Research Institute, Ayub Agriculture Research Institute (AARI), Faisalabad, Pakistan
}

Copyright $\bigcirc 2018$ by authors, all rights reserved. Authors agree that this article remains permanently open access under the terms of the Creative Commons Attribution License 4.0 International License

\begin{abstract}
The rust fungi especially emergence of new rust races has serious threat to global wheat production. This is mainly due to the widespread use of race-specific seedling resistance genes and evolution of new virulence races like $\operatorname{Yr} 9$, $\operatorname{Yr} 27$, and $S r 31$. Several quantitative disease resistance (QDR) or durable resistance genes i.e. Lr34/Yr18/Pm38/Sr57, Lr46/Yr29/Pm39/Sr58, Lr67/Yr46, Lr68 providing resistance to rust diseases at either high or low temperatures have been identified. But, changing climatic conditions affect the level of resistance in cultivars, as at high temperature $\operatorname{Lr} 34 / \mathrm{Yr} 18$ genes which confer durable resistance in wheat become less effective and at low temperature it provides high resistance. While in contrast, yellow rust resistance genes; Yr36 and Yr39 confer resistance at high temperature and later growth stages. This review provides a detailed discussion on, the different aspects of climate change that how it affect host resistance and pathogenic variability and its sustainable control by developing cultivars with high level durable resistance.
\end{abstract}

Keywords Adult Plant Resistance, Bread Wheat, Climatic Conditions, Environmental Variability, Host Resistance, Virulent Races

\section{Introduction}

Climate change has important implications for nearly every aspect of life on earth particularly food crops. Therefore, the task of fulfilling the increasing demand for food in general and wheat in particular is very challenging under the current scenario of climate change [2]. Wheat is widely grown and consumed cereal in the world and its demand is expected to grow due to increasing population, change in food habits in favor of wheat and nutritional requirements [22]. Despite adverse effect of biotic and abiotic stresses, Pakistan stands at $9^{\text {th }}$ position in the world wheat production and considered 4th largest producer of wheat in Asia [7]. Among the various limiting factors affecting wheat yield, the rust fungi especially emergence of new rust races proved serious threat to global wheat production. The intensity of yield losses due to all three rusts of wheat, viz. black, brown and yellow caused by Puccinia graminis tritici, P. triticina and P. striiformis respectively, depends upon the resistance level of the germplasm. In case of highly susceptible varieties, losses may escalate as high as $80 \%$ [11]. According to Saari and Prescott [20] stem rust was historically a major problem in all of Africa, the Middle East, all of Asia except Central Asia, Australia and New Zealand, Europe, and the Americas (both North and South). Stem rust resistance in wheat cultivars with $\mathrm{Sr} 31$ remained effective and durable for more than 30 years. New isolates of Puccinia graminis $\mathrm{f}$. sp. tritici with virulence to $\mathrm{Sr} 31$ were detected in Uganda in 1999 [27] with changing climatic conditions.

Wheat rusts can be controlled worldwide by planting resistant varieties. Use of fungicides for wheat rust is not economically feasible and only recommended as an emergency control measure until resistant wheat varieties are again available. Some very effective chemicals are now available for the control of rusts, especially stripe rust and leaf rust, and with timely application effective stem rust control can also be achieved. However, among all disease management strategies, the use of resistant cultivars is the best disease control strategy, since it comes at no extra cost to the farmer and is environmentally safe [24]. But the 
breeding small grain crops for rust resistance is not like breeding for better grain quality, higher yield, or even tolerance to physical stresses such as drought or heat. Breeding gains made in those traits remain for as long as a variety is grown but it is not true for gains in rust resistance. Resistance built into a wheat variety over 15 years of breeding work can be totally wiped out by a shift in pathogenic races in the rust fungus population. According to the scientists of Cereal Disease Laboratory, University of Minnesota, USA, many major genes confer resistance against all three types of wheat rust, but none of them can be expected to work against all races. Resistances based on single, major, race specific genes often become ineffective within five years of their development, producing "boom and bust" cycles in wheat production. The "bust" cycles (when rust resistance has been overcome) are caused either by pathogens mutating to acquire virulence, a virulent race migrating into a new region or sexual and asexual recombination in the pathogen. The early detection of new virulences in pathogen population makes it possible to replace susceptible cultivars with resistant cultivars in time to avoid large-scale epidemics [24]. This review not only presents basic and recent information on the changes in host resistance and pathogen virulence but also discuss the successful host resistance breeding program under changing climatic conditions.

\section{Host Resistance under Changing Climatic Conditions}

It is extremely difficult to breed a variety that will show resistance to all the races and bio-types of all three rust due to changing climatic conditions that increases the problem of varying races of pathogens that ultimately break the resistance of host [9]. Singh et al. [24] reported that the existence of pathogen genotype by host genotype interactions can have a profound impact on the rate at which pathogens evolved and increased virulence on host plants and the durability of resistance. Lillemo [11] concluded that partial resistance genes with different mechanisms need to be combined to achieve a stable resistance performance across different environments. Some resistance gene combinations, such as the ' $\mathrm{Sr} 2$ complex' for stem rust resistance $[12,15]$, the 'Frontana complex' for leaf rust resistance ([16], a resistance of Anza and Little Joss varieties for yellow rust [8], have shown long time durability. Changing climatic conditions also affect the level of resistance in a cultivar, which expresses when the weather becomes warm and plants grow old. For example $Y r 5$-mediated associated with race specific and Yr39-mediated race non-specific adult plant resistance under high temperature condition vary with changing climatic conditions [11]. In wheat expression of many resistance genes to leaf, stripe and stem rust is determined by temperature and/or plant developmental stage and resistance either breaks down or becomes less effective at high temperature. For example, rust reaction of wheat varieties with the stem rust resistance gene $\mathrm{Sr} 15$ can change from resistant at $15^{\circ} \mathrm{C}$ to nearly fully-susceptible at $20^{\circ} \mathrm{C}[10]$.

The successful host resistance breeding program is mainly based both on understanding of virulence variation in pathogen population as well as identification of new resistant breeding sources. The most important step in successful rust resistance breeding is the understanding virulence variation in pathogen population due to changing climate because without knowledge this variation in cereal rust populations, success in genetic control could not be achieved. Therefore, the plant pathologists and plant breeders have long understood the importance of pathogen variation to the effectiveness and durability of host resistance. Samborski and Roelf suggested that the approach to monitoring pathogen populations has been tremendously valuable in the development and deployment of host resistance [17, 20].

According to different rust pathologists, the identification, characterization and introgression of new resistant breeding sources to cereal rust (plants that may be less desirable in other way, but which carry a useful disease resistance traits) is the second most important step in successful rust resistance breeding followed by crossing of desirable parents for combining major and minor resistance genes in a cultivar as well as testing of breeding populations (filial generations from F1 to F7 and advanced lines) both at seedling and adult plant stages under artificial rust epidemic conditions [20]. But during testing of breeding populations, careful attention must be paid to the types of pathogen isolates that are present, as there can be significant variation in the effectiveness of resistance against different isolates of the same pathogen. Also try to increasing the diversity of resistance genes in our cereal and staying ahead of these "shifty" pathogens. Ancient plant varieties and wild relatives are very important to preserve because they are the most common sources of enhanced plant disease resistance. McIntosh [13] demonstrated that seventy one leaf rust resistance genes in wheat have been mapped to chromosomal locations and given gene designations.

Most resistance genes i.e. $L r 1, L r 10 \& L r 21$ are the good examples of race specific resistance as it remains effective both in seedling and adult plant stage. While race non-specific resistance genes i.e. $\operatorname{Lr} 34, \operatorname{Lr} 46, \operatorname{Lr} 67$ and Lr68 showed a partial type of resistance. This type of resistance has provided long-term durable resistance that optimally expressed in adult plants, as seedlings remained susceptible. The semi dwarf and dwarf varieties developed at CIMMYT, Mexico in the early days of green revolution retained their resistance until they were displaced from commercial cultivation of new high yielding varieties due 
to their genetic potential [3]. It was found that pleiotropic resistance genes i.e. $L r 34 / Y r 18 / P m 38$ and $L r 46 / Y r 29 / P m 39$ confer APR and can be identified through morphological markers i.e. leaf tip necrosis [1]. High levels of resistance can be acquired by combining multiple adult-plant resistance genes in the same cultivar [23]. Under changing climatic conditions, High Temperature Adult Plant (HTAP) resistance contributes to sustainable control of stripe rust by reducing inoculum from season to season in a large scale region, a phenomenon that can be referred as "inoculum decline". Through such inoculum decline, partially resistant HTAP resistant cultivars can be protected from yield losses. High levels of HTAP resistance can be achieved by pyramiding different genes for HTAP resistance. HTAP resistance genes also can be combined with effective all-stage resistance genes to develop cultivars with high-level and durable resistance [26]. An overview of durable wheat rust resistance with respect to changing climatic conditions is described in Table 1.

Table 1. The influence of temperature on the effectiveness of leaf, stripe and stem rust resistance genes

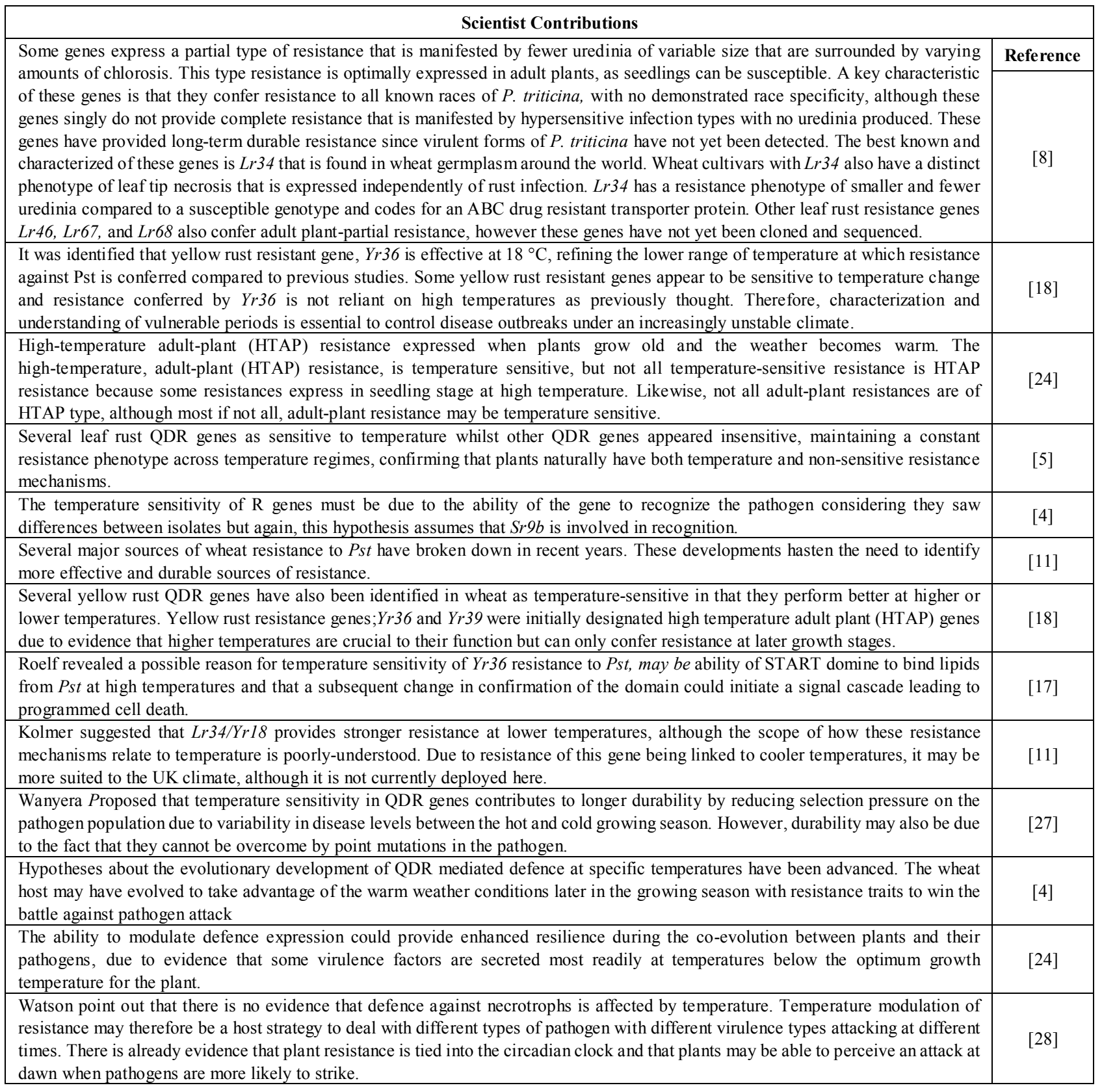




\section{Pathogenic Variability under Changing Climatic Conditions}

Rust fungi are important components of ecological communities and in ecosystem function. Their unique life strategies as biotrophic pathogens with complicated life cycles could make them vulnerable to global environmental change. While there are gaps in our knowledge, especially in natural plant-rust systems, this review of the exposure of rust fungi to global change parameters revealed that some host-rust relationships would decline under predicted environmental change scenarios, whereas others would either remain unchanged or become more prevalent [25].

According to James Kolmer [7], variation in cereal rusts has traditionally been assessed by testing isolates on host genotypes that differ for resistance. The early differentials for wheat stem rust and wheat leaf rust were collections of cultivars and varieties that had different infection types on seedling plants to the most commonly found isolates of both rust pathogens. These early differential sets were genetically undefined as there was no information on the resistance genes present in the cultivars. Many of the early differentials had more than one resistance gene and also had genes in common which reduced their effectiveness in distinguishing rust races. Later as knowledge was gained about the genetics of rust resistance in wheat, cultivars with identified single genes for rust resistance were used as differentials. As an increased number of rust resistance genes were characterized in wheat germplasm, single resistance genes were transferred into single wheat genotype backgrounds by backcrossing. Isogenic differential lines have been developed for all three rusts of wheat and also for oat crown rust. Single gene differentials that are not isogenic lines are still used in Australia for wheat stem rust and wheat leaf rust virulence surveys. Virulence surveys of the three wheat rusts and oat crown rust are conducted annually in the US, Canada, Australia and other countries as well. Races of rust are determined based on qualitative infection types of the isolates on each differential line that are classified as avirulent or virulent. The goals of the surveys are to determine pathogenic variation present in the rust populations and to detect any new races of rust that may pose a threat to the commonly grown cultivars. Furthermore, rust isolates obtained from the surveys can be used in testing cereal germplasm for rust resistance. The most common stem rust races are avirulent to the most wheat cultivars and do not represent any threat to wheat production, yet some winter wheat cultivars are susceptible to these avirulent races. Occasionally stem rust races with increased virulence are detected; however these races have not increased in frequency. In contrast many different races of $P$. triticina are found in North America; in the US between 50 and 60 races are identified annually. $P$. coronata is likely the most variable of the cereal rusts in North America due to the prevalence of buckthorn and the production of sexually derived aeciospores with new combinations of virulence on an annual basis.

Since rusts are obligate parasites, any resistance genes in host cultivars that curtail or eliminate rust reproduction will place tremendous selection pressure on variants that are virulent to the resistance genes. The widespread use of wheat cultivars with different leaf rust resistance genes has resulted in different leaf rust races being found in the major wheat production regions of the US. Soft red winter wheat cultivars are grown in the southern states, eastern states, and in the Ohio Valley region. The soft red winter wheat cultivars in these states commonly have leaf rust resistance genes $\operatorname{Lr} 9, \operatorname{Lr} 11, \operatorname{Lr} 18$ or $\operatorname{Lr} 26$, which have selected for races with virulence to these genes. Similarly the hard red winter wheat cultivars grown in the southern-mid Great Plains region from Texas to Nebraska have been selected for races with virulence to $\operatorname{Lr} 17, \operatorname{Lr} 24, \operatorname{Lr} 26$, and $\operatorname{Lr} 39 / 41$ due to the presence of these genes in the hard red winter wheat cultivars. The hard red spring wheat cultivars grown in Minnesota, North Dakota and South Dakota have resistance genes $L r 2 a, L r 16, L r 23$, and $L r 21$. Leaf rust races with virulence to these genes are commonly found in the Northern Great Plains.

Leaf rust races with virulence to resistance genes in the hard red winter wheat cultivars are also found in the southeastern states and in the spring wheat region of the northern plains, even though cultivars in these regions did not directly select for these races. In the last 20 years DNA based markers have been used to characterize cereal rust populations, and thus have given new insights into the origin and spread of rust genotypes. DNA markers are not directly selected by host genotypes, and are thus unbiased markers that can be used for population genetic analyses. Markers based on random amplified DNA polymorphism (RAPD), amplified fragment length polymorphism (AFLP) and simple sequence repeat (SSR) polymorphism have been used and developed for studies of $P$. triticina populations in North America. Although the markers differ in ability to detect polymorphism among different groups of $P$. triticina, the results between the different studies were very consistent. Of the three markers, SSRs likely offer the optimal combination of sufficient levels of polymorphism, ability to distinguish multiple alleles at single locus, ease of scoring allele molecular weights, and repeatability across experiments. Currently in North America, there are six groups of $P$. triticina races based on SSR genotype groupings. Isolates within the SSR groups are identical or highly related for SSR genotype, and are also related to virulence to key leaf rust resistance genes. Isolates in different SSR groups are distinct for SSR genotype and are usually highly different for virulence as well. Two SSR groups that are found throughout the Great Plains region and the southern and eastern states, NA-3 and NA-5, account for $95 \%$ of the isolates in the current $P$. triticina population. One small group of isolates, NA-2 is found mainly in the soft white wheat regions of upstate 
New York and Washington State. Isolates from California, Arizona, and Mexico that are virulent to durum wheat are also distinct for SSR group and are in NA-6. The $P$. triticina population in the US and worldwide has characteristics of highly clonal populations as evidenced by high levels of observed heterozygosity relative to expected levels under random mating, high levels of linkage disequilibrium between SSR markers, and a general correlation between virulence and SSR genotypes. If aeciospores derived from sexual recombination contributed regularly to epidemic development it would be expected that observed heterozygosity levels would be close to expected levels, most SSR markers would be in equilibrium, and that there would be no relationship between virulence and SSR genotype. Molecular markers and virulence have also been used to characterize worldwide $P$. triticina populations in order to determine their genetic relationships and possible migration between continents. Collections of $P$. triticina from Uruguay, Argentina, Chile, and Brazil were highly similar or in a few cases identical for SSR genotype to the NA3 and NA5 SSR groups in North America. Isolates in the NA3 SSR group and the related SA3 group in South America were likely introduced from the same origin, as both were detected and become common in the mid and late 1990s in North America and South America, respectively. Similarly collections of P. triticina from durum wheat in Europe, South America, Mexico and the Middle East were nearly identical for SSR genotype and for virulence, which implied a common origin of these isolates [25].

Many spring wheat cultivars in the US and Canada have leaf rust resistance genes $\operatorname{Lr} 13$ and $L r 34$. In recent years, cultivars with these resistance genes have suffered higher levels of rust infection since many $P$. triticina genotypes are now virulent to $\operatorname{Lr} 13$ and produce intermediate levels of infection on lines with $L r 34$. Wheat cultivars from North America and other parts of the world are genetically examined to determine their leaf and stem rust resistance genotype. Effective genes on rust resistance from different sources can then be transferred to locally adapted wheat germplasm. The impact of environment and pathogenic variability on wheat leaf rust resistance genes in wheat describe by McIntosh et al. [13] is given in Table.2. 
Impact of Environmental and Pathogenic Variability on Breaking of Host Rust Resistance in

Wheat Cultivars under Changing Climatic Conditions

Table 2. Influence of environmental and pathogenic variability on host leaf rust resistance genes present in wheat

\begin{tabular}{|c|c|c|c|c|}
\hline \multirow{2}{*}{ Genes } & \multicolumn{2}{|c|}{ Chromosomal } & \multirow{2}{*}{$\begin{array}{l}\text { Pathogenic } \\
\text { Variability }\end{array}$} & \multirow{2}{*}{ Environment variability } \\
\hline & Location & Linkage & & \\
\hline Lrl & $5 \mathrm{DL}$ & - & Globally polymorphic with respect to host lines possessing $\operatorname{Lr} l$. & $\begin{array}{l}\text { Low variability. Showed high infection types at very low temperature i.e. } 5^{\circ} \mathrm{C} \\
\text { conditions were sufficient to produce full resistance. }\end{array}$ \\
\hline $\operatorname{Lr} 2 a$ & 2DS & - & $\begin{array}{l}\text { Population tends to be polymorphic worldwide. } L r 2 a \text { is effective against predominant } \\
\text { pathotypes in eastern Australlia. }\end{array}$ & $\begin{array}{l}\text { Medium variability. Low infection type response varied with pathogen isolate and } \\
\text { temperature. } \operatorname{Lr} 2 a \text { is slightly more effective at higher temperatures. }\end{array}$ \\
\hline$L r 2 b$ & 2DS & - & Pattern of response is similar to $\operatorname{Lr} 2 a$. & Medium variability. Similar to $L r 2 a$. \\
\hline $\operatorname{Lr} 2 c$ & 2DS & - & $\begin{array}{l}\text { Both avirulence and virulence to } L r 2 c \text { occurs in most geographical regions. Avirulence in } \\
\text { Australlia is limited to a single pathotype. }\end{array}$ & $\begin{array}{l}\text { Moderate variability. Temperature from } 10{ }^{\circ} \mathrm{C} \text { to } 25^{\circ} \mathrm{C} \text { had little effect on low } \\
\text { infection type. }\end{array}$ \\
\hline $\operatorname{Lr} 3 a$ & $6 \mathrm{BL}$ & $\operatorname{Sr} 11$ & $\begin{array}{l}\text { Pathogen populations are polymorphic in most geographic areas, but because this gene is } \\
\text { present in cultivated wheats in many geographic regions the frequencies of virulence are often } \\
\text { very high. }\end{array}$ & $\begin{array}{l}\text { Low variability. Low infection type showed variability with decreasing } \\
\text { temperatures in respect to one pathogen culture. }\end{array}$ \\
\hline Lr3bg & $6 \mathrm{BL}$ & Srl1 & $\begin{array}{l}\text { This allele produces IT } 0 \text {; to cultures avirulent on seedlings with } L R 3 a \text {, and produces } \\
\text { intermediate reactions to certain additional cultures. }\end{array}$ & Low variability. \\
\hline$L r 3 k a$ & $6 \mathrm{BL}$ & $\operatorname{Sr} 11$ & $L r 3 K a$ confers a wide range of resistance than other Lr3 alleles. & $\begin{array}{l}\text { Low. Assumed to be influenced by pathogen culture and observed temperature } \\
\text { sensitive responses with one of their cultures. }\end{array}$ \\
\hline $\operatorname{Lr} 9$ & $6 \mathrm{BL}$ & - & Virulence for $\operatorname{Lr} 9$ was found in the USA in 1971, four year after its use in soft red winter wheats. & Low variability. \\
\hline Lr10 & IAS & - & $\begin{array}{l}\text { Pathogenic polymorphisms for } \operatorname{Lr} 10 \text { occur in North America and some variation is apparent in } \\
\text { the UK, Europe, Africa, South and East ASIS and South America. With one recent exception, } \\
\text { Lr10 has not been effective in Australasia since formal testing was initiated in the } 1920 \text { s. }\end{array}$ & Medium. \\
\hline Lr11 & $2 \mathrm{~A}$ & - & $\begin{array}{l}\text { P. recondita tritici populations are widely polymorphic on seedlings with this gene. Virulence } \\
\text { for Lr11 increased in texas from } 1985 \text { to } 1990 \text { (Marshall, 1992), in the USA generally in } \\
\text { 1988-1990 and in Canada from } 1990 \text { to } 1999 \text {. Virulence was less frequent in Mexico and South } \\
\text { Africa. }\end{array}$ & $\begin{array}{l}\text { High (William and Johnson, 1956).more effective at lower temperature. } \\
\text { Background genotypes also have an important influence on low infection type. }\end{array}$ \\
\hline Lr12 & 4BS & - & $\begin{array}{l}\text { Variability probably occurs in most geographic areas. Virulence occurs in a related group of } \\
\text { pathotypes in Australia. }\end{array}$ & Presumed to be stable, but no information is available. \\
\hline Lr13 & 2BS & $\begin{array}{l}\mathrm{Ne} 2 m \\
\mathrm{Lr} 23\end{array}$ & $\begin{array}{l}\text { Because of the temperature sensitivity, pathogenic variability is uncertain. However virulence is } \\
\text { known to occur in North America, South Africa, the Indian subcontinent, and Australia where a } \\
\text { single pathotype is virulent. }\end{array}$ & High. Seedling resistance conferred by $\operatorname{Lr} 13$ is more effective at higher temperature. \\
\hline $\operatorname{Lr} 14 a$ & $7 \mathrm{BL}$ & - & $\operatorname{Lr} 14 a$ is no longer widely effective in any geographical area. & High variability. $\operatorname{Lr} 14 a$ was observe to be more effective at temperature below $20^{\circ} \mathrm{C}$ \\
\hline $\operatorname{Lr} 14 b$ & 7BL & - & Comparatively little is known of pathogenic variability on wheats with $\operatorname{Lr} 14 b$. & Less effective at warmer temperature \\
\hline $\operatorname{Lr} 15$ & 2DS & $\operatorname{Lr} 2, \operatorname{Sr} 6$ & $\begin{array}{l}\text { Pathogenic variability occurs in most geographic areas. Frequencies of avirulence are very high } \\
\text { in Australia. }\end{array}$ & Low variability. \\
\hline Lr16 & 2BS & $\operatorname{Sr} 23$ & $\begin{array}{l}\text { Variation occurs in most geographic areas, but the frequency of virulence is usually relatively } \\
\text { low. }\end{array}$ & $\begin{array}{l}\text { Lr16 is more effective at higher temperature and the environmental sensitivity } \\
\text { varied with pathogen isolates. }\end{array}$ \\
\hline Lr17 & $2 \mathrm{AS}$ & $\begin{array}{l}\text { Lr37, } \\
\text { Sr38, } \\
\text { Yr17 }\end{array}$ & Variation occurs in most geographic areas. & $\begin{array}{l}\text { Seedling with } \operatorname{Lr} 17 \text { becomes more resistant to avirulent cultures at higher } \\
\text { temperature. }\end{array}$ \\
\hline Lr18 & $5 \mathrm{BL}$ & - & Pathogenic variation on seedlings with $\operatorname{Lr} 18$ with avirulence usually predominating. & $\begin{array}{l}\text { High variability. } L r 18 \text { becomes increasingly ineffective as temperature increase to } \\
\qquad 25^{\circ} \mathrm{C} .\end{array}$ \\
\hline $\operatorname{Lr} 19$ & 7DL & $\operatorname{Sr} 25$ & Virulence is rare & Low variability. \\
\hline
\end{tabular}




\begin{tabular}{|c|c|c|c|c|}
\hline $\operatorname{Lr} 20$ & $7 \mathrm{AL}$ & $\begin{array}{c}\text { Pm1, S15, } \\
\text { Sr22 }\end{array}$ & Pathogenic variation only occur in Indian subcontinent & $\begin{array}{l}\text { Lower response occurs at lower temperature. } L r 20 \text { become completely ineffective } \\
\text { at } 30^{\circ} \mathrm{C} .\end{array}$ \\
\hline $\operatorname{Lr} 21$ & $1 \mathrm{DL}$ & - & $\begin{array}{l}\text { Virulent isolates have not been found in North America or Australia. Despite claims of } \\
\text { ineffectiveness in seedlings, adult plants with } L r 21 \text { are resistant on the Indian subcontinent }\end{array}$ & Low variability. \\
\hline$L r 22 a$ & 2DS & $\mathrm{Tg}, W 2$ & Virulence unknown. Observations are from field sowings & Low variability. \\
\hline$L r 22 b$ & 2DS & $T g, W 2$ & Virulence occur & Low variability. \\
\hline $\operatorname{Lr} 23$ & 2BS & $\operatorname{Lr} 13, \operatorname{Sr} 9$ & $\begin{array}{l}L r 23 \text { is no longer widely effective in most geographic areas except Europe. Virulence for } L r 23 \\
\text { is common in Australia and Mexico. In most areas pathogenicity for } L r 23 \text { shows a wide range of } \\
\text { variation over space and time. }\end{array}$ & High variability. $\operatorname{Lr} 23$ is more effective at temperature above $20^{\circ} \mathrm{C}$. \\
\hline $\operatorname{Lr} 24$ & $3 \mathrm{DL}$ & $\operatorname{Sr} 24$ & $\begin{array}{l}\text { Virulence for } \operatorname{Lr} 24 \text { occurs in North America, South America and South Africa. Virulence for } \\
\text { Lr24 occurs at low frequencies in most other geographical areas but has not been found in } \\
\text { Australia or India. }\end{array}$ & Moderate variability. Showed higher IT at low temperature \\
\hline $\operatorname{Lr} 25$ & 4BS & $\operatorname{Pm} 7$ & $\begin{array}{c}\text { Virulence has been detected in Canada, Algeria, China, Bulgaria, Egypt, Ethiopia, Hungary, } \\
\text { Israel and Pakistan. }\end{array}$ & Low variability. \\
\hline $\operatorname{Lr} 26$ & 1BL & $\operatorname{Sr} 31, \operatorname{Yr} 9$ & $\begin{array}{l}\text { Although variation in the avirulence phenotype is common, full virulence has emerged in most } \\
\text { wheat-growing areas; for example, Europe, the Indian subcontinent, North America and South } \\
\text { Africa }\end{array}$ & There is no response on the effect of environment. \\
\hline $\operatorname{Lr} 27$ & 3BS & $\operatorname{Sr} 2$ & Pathogenic variability occurs in Australia, Mexico and most other geographic regions. & $\begin{array}{l}\text { Probably moderate. At high temperature chlorosis associated with } \operatorname{Sr} 2 \text { can obscure } \\
\text { the low infection type. }\end{array}$ \\
\hline $\operatorname{Lr} 28$ & $4 \mathrm{AL}$ & - & $\begin{array}{l}\text { Several spontaneous mutants with virulence for } \operatorname{Lr} 28 \text { have been isolated in Australia. The } \\
\text { frequency of virulence for this gene is extremely high in North America. Virulence has not been } \\
\text { found in India but Huerta-Espino (1992) found virulence among isolates from Pakistan and } \\
\text { from most other major geographic areas. }\end{array}$ & Low variability. \\
\hline $\operatorname{Lr} 29$ & 7DS & - & $\begin{array}{l}\text { In a global survey Huerta-Espino (1992) found only three isolates with virulence on seedlings } \\
\text { with Lr29; one from Pakistan and two from Turkey. }\end{array}$ & Low variability. \\
\hline $\operatorname{Lr} 30$ & 4BL & - & Virulence for $\operatorname{Lr} 30$ is infrequent in Australia, Mexico and Canada & Higher responses to avirulent pathotypes are obtained at higher temperature. \\
\hline $\operatorname{Lr} 31$ & 4BS & - & $L r 31$ acts as a complementary gene with $L r 27$. See $L r 27$. & $L r 31$ acts as a complementary gene with $L r 27$. See $L r 27$. \\
\hline Lr32 & $3 \mathrm{D}$ & - & Appears to be effective against all pathotypes in Australia and Mexico. & Unknown; presumed to be stable. \\
\hline $\operatorname{Lr} 33$ & $1 \mathrm{BL}$ & $\operatorname{Lr} 26$ & $\begin{array}{c}\text { All Australian isolates appear virulent on seedlings with } L r 33 \text {, but a degree of resistance was } \\
\text { expressed on adult plants in the greenhouse. Pathogenic variability on seedlings of the line with } \\
L r 33 \text { occurred in most geographical areas. In some instances low responses were recorded for } \\
\text { the } L r 33+L r 34 \text { stock, whereas the respective } L r 33 \text { and } L r 34 \text { single gene lines gave high } \\
\text { responses. }\end{array}$ & Unknown \\
\hline $\operatorname{Lr} 34$ & $7 \mathrm{D}$ & $\begin{array}{l}Y r 18 \\
B d v 1\end{array}$ & $\begin{array}{l}\text { Presumably not common. Dyck and Samborski (1982) reported a unique culture (10-77) } \\
\text { isolated from cv. Tobari } 66 \text { ( } \operatorname{lr} 1 \text { Lr13 Lr34) and virulent on seedlings of R. L. } 6050(\operatorname{Lr} 34) \text {. This } \\
\text { culture was also virulent on seedlings of Frontana and four additional lines produced at } \\
\text { CIMMYT, but was not virulent on adult plants with } L r 34 \text {. }\end{array}$ & $\begin{array}{l}\text { Infection types can vary from } 0,1^{-} \text {to } 3 \text { depending on temperature and light. } \\
\text { Infection type is lowest under conditions of "cool temperature and low light } \\
\text { intensity". Showed lower responses at } 18-22^{\circ} \mathrm{C} \text { compared with } 24-27^{\circ} \mathrm{C} \text {. Seedling } \\
\text { resistance has been very difficult to detect under the normal range of greenhouse } \\
\text { conditions. }\end{array}$ \\
\hline $\operatorname{Lr} 35$ & $2 \mathrm{~B}$ & Sr32 & Not reported, but not widely tested. & Unknown \\
\hline $\operatorname{Lr} 36$ & 6BS & - & None reported. & None reported \\
\hline $\operatorname{Lr} 37$ & $2 \mathrm{AS}$ & $\begin{array}{r}\text { Sr38, } \\
\text { Yr17 }\end{array}$ & Unknown & $\begin{array}{l}\text { Seedling resistance is more effective at lower temperature, for example } 17^{\circ} \mathrm{C} ; \\
\text { Temperature above } 20^{\circ} \mathrm{C} \text { resulted in infection types ranging from } \mathrm{X}^{+} \text {to } 3^{+} \text {(Bariana }\end{array}$ \\
\hline
\end{tabular}


Impact of Environmental and Pathogenic Variability on Breaking of Host Rust Resistance in

Wheat Cultivars under Changing Climatic Conditions

\begin{tabular}{|c|c|c|c|c|}
\hline & & & & 1991) \\
\hline $\operatorname{Lr} 38$ & $2 \mathrm{AL}$ & - & Unknown & Low. \\
\hline $\operatorname{Lr} 39$ & 2DS & - & - & - \\
\hline $\operatorname{Lr} 40^{*}$ & & - & - & - \\
\hline $\operatorname{Lr} 41^{*}$ & & - & - & - \\
\hline Lr42 & $1 \mathrm{D}$ & - & - & - \\
\hline Lr43* & & - & - & - \\
\hline Lr44 & $1 \mathrm{BL}$ & - & - & - \\
\hline $\operatorname{Lr} B$ & - & - & $\begin{array}{l}\text { Although } L r B \text { is ineffective in Australia, the Thatcher near-isogenic line with } \operatorname{Lr} B \text { provided } \\
\text { differential responses in most geographic areas. }\end{array}$ & \\
\hline
\end{tabular}




\section{Conclusions}

This review covers all successful steps for enhancing host rust resistance in wheat under changing climate condition. From this it is concluded that both the changes in environment and pathogen population affect the resistance level of host plant. The long-term success of breeding for disease resistance is influenced by three factors, firstly the nature of the pathogen and diversity of virulence in the population, secondly the availability, diversity and type of genetic resistance and thirdly the screening methodology and selection environment for tracking resistance. Due to the highly variable nature of rust pathogen, durable leaf rust resistance in wheat cultivars has been difficult to achieve. Additional effective resistance genes are required for wheat genotypes to reduce the probability of simultaneous pathogen mutations to virulence and should avoid stepwise erosion of the pyramid by preventing significant reproduction of any new race that is virulent on component genes. Combination of major genes with minor/adult plant resistance genes is the best strategy for long lasting resistance. At least 10-12 different genes are involved in group of CIMMYT germplasm, and by accumulating 4-5 minor genes, the resistance level near to immunity can be achieved. However 2-3 genes in a line provide moderate level of resistance as shown in Figure below presented by Ravi Singh from International Maiz and Wheat Improvement Center (CIMMYT), Mexico.

\section{REFERENCES}

[1] S. Agarwal, R. G. Saini, A. K. Sharma, L. Kaur and U. K. Bansal. Quantification of leaf tip necrosis, a trait linked with Lr34/ Yr18. Indian Journal of Genetics and plant breedings. 63:304-306, 2003.

[2] S. Ayyappan. Wheat productivity enhancement under changing climate, page forward. Narso Publishing House Pvt Ltd. India. 2012.

[3] N. E. Borlaug. Wheat breeding and its impact on world food supply In: 3rd Inter Wheat Genet Symp, Canberra, Australia, pp 1-36, 1968.

[4] X. M. Chen, T. Coram, X. L. Huang, M. N. Wang and A. Dolezal. Towards an understanding of the molecular mechanisms of durable and non-durable resistance to stripe rust in wheat. Proceeding Borlaug Global Rust Initiative (BGRI) Technical Workshop, St. Paul. Minnesota, USA, 13-16 June. pp. 70-81, 2011.

[5] E. 1. Jarroudi, M. Giraud, B. Tychon, L. Hoffmann, P. Delfosse. First report of the breakdown of the YR17 resistance gene to wheat stripe rust in the grand-duchy of Luxembourg. Journal of Plant Pathology. 93:243. doi:10.4454/jpp.v93i1.300, 2009.

[6] FAO. http://www.fao.org/docrep/018/i3251e/i3251e.pdf, 2013.
[7] FAOSTAT. FAOSTAT. In: Food and Agriculture Organization of the United Nations Rome, Italy, 2013.

[8] K. James. Leaf Rust of Wheat: Pathogen Biology, Variation and Host Resistance. Forests (4): 70-84; doi:10.3390/f4010070, 2013.

[9] R. Johnson. Durable resistance to yellow (stripe) rust in wheat and its implication in plant breeding. Pp63-75 in N.W. Simmonds and S. Rajaram, eds. Breeding strategies for resistance to the rusts in wheat. CIMMYT: Mexico, D.F., 1988.

[10] L.M. Joshi, and S. Sheodhan S. Rust Resistance in varieties of wheat and barley in India. Indian Council of Agricultural Research, 1995.

[11] J. A. Kolmer, Genetics of resistance to wheat leaf rust Annual Reveiw of Phytopathology. 34:435-455, 1996.

[12] M. Lillemo, R.P. Singh, M. William, S. Herrera-Foessel, J. Huerta-Espino, S. Germán, P. Campos, M. Chaves, R. Madriaga, X. C. Xia, S. Liang, Z. F. Liu and E. S. Lagudah. Multiple rust resistance and gene additively in wheat: Lessons from multi-location case studies in cultivars Parula and Saar Proceeding of Borlaug Global Rust Initiative (BGRI) Technical Workshop, st. paul, Minnesota, USA, 13-16 June, pp.111-120, 2011

[13] R. A. McIntosh. The role of specific genes in breeding for durable rust resistance in wheat and triticales. Pp 1-9 in N.W. Simmonds and S. Rajaram, eds. Breeding strategies for resistance to the rusts in wheat. CIMMYT: Mexico, D.F. 1988.

[14] R. A. McIntosh, Y. Yamazaki, J. Dubcovsky, W.J. Rogers, C. Morris, R. Appels, K.M. Devos. Catalogue of gene symbols for wheat. 2010. In KOMUGI Integrated Wheat Science Database. Available online:

www.shigen.nig.ac.jp/wheat/komugi/genes (accessed 17 October 2012).

[15] Z. A. Pretorius, R.P. Singh, W.W. Wagoire, T.S. Payne. Detection of virulence to wheat stem rust resistance gene Sr31 in Puccinia graminis. f. sp. tritici in Uganda. Plant Disease. 84:203-203. doi:10.1094/PDIS.2000.84.2.203B, 2000 .

[16] S. Rajaram, R. P. Singh and E. Torres. Current approaches in breeding wheat for rust resistance. In: Breeding strategies for resistance to rusts of wheat. Symmonds NW, Rajaram S. (eds) CIMMYT, Mexico D.F., Mexico. pp 101-118, 1988.

[17] A.P. Roelf. Resistance to leaf and stem rusts of wheat. Pp 10-22 in N.W. Simmonds and S. Rajaram, eds. Breeding strategies for resistance to the rusts in wheat. CIMMYT: Mexico, D.F. 1988.

[18] A.P. Roelfs. Epidemiology in North America. In A.P. Roelfs \& W.R. Bushnell, eds. The cereal rusts, vol. 2, Diseases, distribution, epidemiology, and control, p. 403-434. Orlando, FL, USA, Academic Press, 1985.

[19] R.M.B. Ruth, G. R. D. McGrann, A. R. Mitchell, H. Schoonbeek, L. A. Boyd, C. Uauy, S. Dorling and C. J. Ridout. A change in temperature modulates defence to yellow (stripe) rust in wheat line UC1041 independently of resistance geneYr36. MC Plant Biology 14:10 DOI: 10.1186/1471-2229-14-10. 
[20] E. E. Saari and J. M. Prescott. World distribution in relation to economic losses. In A.P. Rcelfs \& W.R. Bushnell, eds. The cereal rusts, vol. 2, Diseases, distribution, epidemiology, and control, p. 259-298. Orlando, FL, USA, Academic Press, 1985.

[21] D.J. Samborski. Wheat leaf rust. In A.P. Rcelfs and W.R. Bushnell, eds. The cereal rusts, vol. 2, Diseases, distribution, epidemiology, and control, p. 39-59. Orlando, FL, USA, Academic Press, 1985.

[22] S. S. Singh National Efforts for increasing wheat productivity In: Wheat productivity enhancement under changing climate page.25-30, 2012.

[23] R.P. Singh, J. Huerta-Espino and H.M. William. Genetics and breeding of durable resistance to leaf and stripe rusts in wheat. Turk. J. Agric., 29: 121-127, 2005.

[24] D. Singh, R.F. Park and R.A. McIntosh. Inheritance of seedling and adult plant resistance to leaf rust of selected Australian spring and English winter wheat. Plant Disease. 79: $35-38,2001$

[25] R.P. Singh and J. Huerta-Espino. Global monitoring of wheat rusts and assessment of genetic diversity and vulnerability of popular cultivars. Research. Highlight of CIMMYT wheat program: 1999-2000. CIMMYT, Mexico, 2000.

[26] H. Stephan Rust fungi and global change. New Phytologist 201: 770-780, 2014.

[27] R. M.G. Wanyera, Kinyua, Y. Jin and R.P. Singh. The spread of stem rust caused by Puccinia graminis $s p$. tritici with virulence on $\mathrm{Sr} 31$ in wheat in Eastern Africa. Plant Disease. 90: 113, 2006.

[28] I.A. Watson. 1914-1986. http://www.asap.unimelb.edu.au/bsparcs/watson.htm. 